\title{
Vstup do prostoru koncentračního tábora jako přechodový rituál
}

\author{
Markéta Páralová Tardy
}

\begin{abstract}
Abstrakt
Přechodové rituály, jejichž teorii definoval francouzský antropolog Arnold van Gennep, Ize úspěšně aplikovat také na prostředí koncentračních táborů. Podstatou každého přechodového rituálu je změna společenského statusu, k niž dochází také prĭi vstupu do tábora. Přijezd do tábora je pro vězně určitou formou transgrese a transformace, která probíhá ve třech fázích (preliminální, liminální a postliminálni). Schéma této postupné transformace je vymezeno taktéž prostorově (rampa, brána, sauna a karanténa). Analýza vybraných literárních děl bývalých vězňu se soustředí na jednotlivé dilčí etapy přechodového rituálu, který začínal po prřijezdu na rampě, pokračoval průchodem branou a v sauně stř̆háním vlasů, výměnou oděvu a tetováním čísla, končil několikatýdenním pobytem v karanténě. Karanténa byla posledním článkem proměny člověka ve vězně, završením jeho dehumanizace, jejiž snahou bylo vytvorit naprosto poslušnou jednotku nekladoucí odpor.
\end{abstract}

\section{Klíčová slova}

koncentrační tábor; prechodový rituál; transformace; táborová próza

\section{Abstract \\ Entrance into the Concentration Camp Space as a Rite of Passage}

The rites of passage, defined in theory by the French anthropologist Arnold van Gennep, may be successfully applied to the environment of concentration camps. The essence of each rite of passage is the change of one's social status, which also happens upon entering the camp. Coming to the camp itself is a form of transgression and transformation for the prisoners, taking place in three stages (preliminary, liminal and post-liminal). The framework of the gradual transformation is also limited in space (the platform, the gate, the sauna and the detention). The analysis of selected pieces of writing by former prisoners focuses on individual phases of the rite of passage which started after the arrival on the platform, continued upon passing through the gate, then in the sauna by cutting people's hair, changing their clothes and tatooing their numbers, and finished by several days spent in detention. The detention was the last segment of transforming a human into a prisoner, the climax of their dehumanization whose purpose was to create an utterly obedient, non-resistant unit.

\section{Key words}

concentration camp; rite of passage; transformation; camp prose 
Zkoumání kategorie prostoru v literárních dílech často vyžaduje potřebu interdisciplinárního přístupu. Představy o prostoru jsou spojovány s filozofickými, náboženskými a kulturními kategoriemi nebo hodnotami. Prostor může být vnímán jako imaginace, intelektuální konstrukce, které jsou předmětem studia filozofie a dalších humanitních věd. Může být však také pojímán jako představa konkrétního, skutečného prostoru, s níž se pracuje v rámci exaktních věd, avšak také v sociologii, antropologii nebo i v literární vědě. Předkládaná analýza je propojením obou možných přístupů a zároveň využívá nejen literárněvědné badatelské metody, ale zohledňuje i antropologické pojetí prostoru.

Při zkoumání proměn, jimiž vězni po příjezdu do tábora procházeli, můžeme využít teorii přechodových rituálů, jež studoval francouzský antropolog, religionista a etnolog Arnold van Gennep. Popisy přechodových rituálů lze úspěšně aplikovat také na prostředí koncentračních táborů. Podstatou každého přechodového rituálu je změna společenského statusu, kdy hlavní aktér tohoto obřadu přechází z jedné pozice do druhé, přičemž překonává určitou hranici či hranice. Příjezd do tábora znamenal pro vězně určitý druh transgrese a transformace, proto můžeme hovořit o přechodovém rituálu.

Podle Arnolda van Gennepa se každý rituál skládá z dílčích sekvencí, v případě přechodu z jedné situace k jiné nebo z jednoho sociálního světa do druhého můžeme rozlišovat následující kategorie:

- rituály odluky,

- rituály pomezní,

- rituály sloučení. ${ }^{1}$

V časově-prostorovém aspektu můžeme schéma přechodových rituály uspořádat takto:

- rituály preliminální (předprahové, rituály odlučování od předchozího světa),

- rituály liminální (prahové, rituály konané ve stádiu pomezí),

- rituály postliminální (poprahové, rituály přijetí do nového světa). ${ }^{2}$

Je však nutné vzít v úvahu, že ne vždy jsou jednotlivé obřadní sekvence stejnoměrně rozloženy a rozvinuty, dle povahy rituálu získává na významu jiná dílčí sekvence. Význam dané sekvence se může měnit a lišit také v závislosti na jednotlivci, jež rituál podstupuje. V analyzovaných vzpomínkách spatřujeme shodné rysy, ale i četné rozdíly v popisu příjezdu do tábora, což je zdůvodněno odlišným vnímáním a předchozími zkušenostmi vězňů. Kromě toho nelze opomenout takové aspekty, jakými jsou věk, pohlaví, společenské postavení nebo emocionální i psychická rovnováha.

Jak již název napovídá, přechodové rituály se uplatňují také při přechodu z jednoho území na jiné, takový přechod můžeme nazvat materiálním přechodem. Bývalo častým zvykem, že tento přechod vyžadoval různé formality politického, právního nebo hospodářského rázu. Kromě toho však existovaly také formality magicko-náboženské povahy. Do této skupiny spadají zákazy zabraňující křestanům, muslimům nebo jiným věřícím vstupovat na posvátná území lidem jiného vyznání. Aby toto území bylo dobře rozpozna-

1 VAN GENNEP, Arnold: Přechodové rituály. Praha: Lidové noviny, 1996, s. 19.

2 Ibidem, s. 27. 
telné, musí jej od okolí oddělovat jasná hranice, která může mít mnoho podob. Nebylo výjimkou, že kolem tohoto území existovala ještě neutrální zóna. ${ }^{3} \mathrm{O}$ materiálním přechodu lze hovořit také v př́ípadě vstupu do koncentračního tábora. Takový vstup vykazuje mnoho shodných rysů s výše popsanými materiálními přechody. Vězeň opouští dosavadní svět, aby se postupně začlenil do světa nového. Během tohoto procesu začleňování musí projít různými etapami (rituály), které mu pomohou lépe přijmout novou situaci a sžít se s novým světem. Tento stav je pomezím, kdy se vězeň ještě nachází mezi dvěma světy. Tábor (který je pro vězně oním novým světem) má srovnatelné vlastnosti s posvátným územím, nebot byl obehnán hranicemi, jež mu měly zajistit jeho nedotknutelnost. Vstoupit do něj mohla jen určitá skupina vyvolených tak, že tuto hranici překonala a prošla bránou, která symbolizuje práh tohoto „posvátného světa“. Kolem území tábora rovněž existovala tzv. neutrální zóna, která posilovala nedotknutelnost území, ale kromě dalších funkcí sloužila také k jeho ještě větší izolovanosti.

Jednotlivé dílčí sekvence rituálu můžeme znázornit na této časové ose ${ }^{4}$ :

fáze preliminálni fáze liminálni fáze postliminálni

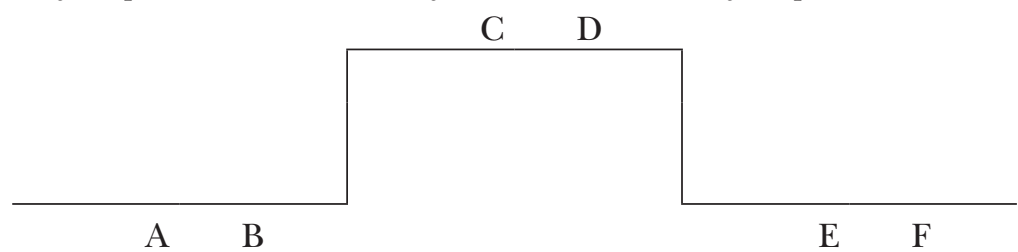

Bod A je výchozím bodem, běží normální profánní čas, vězeň zaujímá své určité postavení v rámci společnosti.

Přechod z A do B - představuje začátek rituálu, v tomto okamžiku je vězeň dopaden při pouliční razii nebo jiným zpơsobem zadržen, zatčen a uvězněn, v bodě $\mathrm{B}$ dochází $\mathrm{k}$ jeho transportu do tábora.

Přechod z B do C - začátek liminální fáze, čas odluky, vězeň prochází branou tábora, vystupuje na rampě, čili poprvé vstupuje do prostoru tábora.

C - D - vězeň je vyloučen ze společnosti, získává status „zuganga“ - nově příchozího, zatím pobývá v karanténě, během liminální fáze dochází $\mathrm{k}$ několika dílčím obřadům, které umocňují vězňovo vyloučení z dosavadní společnosti.

Přechod z D do E - rituál sloučení, vězeň z karantény se zapojuje do běžného táborového života, s čímž je také spojena změna jeho statusu, přestává být „zugangem“ a stává se z něj „häftling“.

$\mathrm{E}$ - F postliminální fáze, kdy jsou dokončeny obřady, jež potvrzují status vězně, který začíná již žít ve svém novém postavení. ${ }^{5}$

3 Ibidem, s. 22-23.

4 Tento výkres je převzat z publikace: KRUPA, Bartłomiej: Wspomnienia obozowe jako specyficzna odmiana pisarstwa historycznego. Kraków: Universitas, 2006, s. 85.

5 KRUPA, Bartłomiej: Wspomnienia obozowe jako specyficzna odmiana pisarstwa historycznego. Kraków: Universitas, 2006, s. 86 . 
Jednotlivé fáze je možné situovat také prostorově:

rampa - první kontakt s novým prostorem,

brána - hranice vněǰšího světa a vnitřního světa tábora,

sauna - začátek obřadu vyloučení,

karanténa - oddělené bloky vyhrazené pro nově příchozí vězně,

tábor - po zhruba měsíční či kratší karanténně se vězeň dostává do tábora mezi řadové vězně, je zařazen do bloku a zapojuje se do pracovního režimu v rámci jednotlivých komand.

V následující části se budu soustředit na analýzu jednotlivých dílčích etap liminální fáze přechodového rituálu, jímž procházel každý nový vězeň koncentračního tábora. Za připomenutí stojí skutečnost, že podobně bychom mohli také nahlížet na evakuaci, pochod smrti a ukončení existence tábora, protože i tyto události doprovázely přechodové rituály.

\section{a) rampa}

Rampa představovala první kontakt $\mathrm{s}$ táborem. Je to místo, kde vězeň získával první táborové zkušenosti. V tomto okamžiku začíná přechodový rituál, jeho liminální fáze. Události na rampě jsou ve své podstatě postupnou intenzifikací sacrum. ${ }^{6}$ Rampa představuje vyvýšenou plošinu, v polštině se kromě výrazu rampa můžeme setkat také se synonymem „pomost“", jenž lze přeložit jako „můstek“ nebo „lávka“. Metaforicky vzato byla tato rampa můstkem mezi vlakem a táborem, jinými slovy: přenášela lidi z vnějšího světa do vnitřního táborového světa. Vězni si uvědomovali, že výstup z vlaku pro ně znamená zlomový okamžik:

To miejsce we wspomnieniach moich nazwałbym momentem, w którym kończyłem z wszystkim, co było dotychczas na ziemi i zacząłem coś, co było chyba gdzieś poza nią. ${ }^{8}$

Rampa v Birkenau nesloužila jako jiné rampy k překládce zboží, ale k překládkám transportů. $S$ vězni se však zacházelo podobně jako se zbožím, což je patrné i v jazykové rovině. Už níže citovaná věta

Załadowano nas do krytych wagonów bydlęcych. ${ }^{9}$

nasvědčuje, jaký bude charakter a průběh jízdy. Stejně tak lze z ní rovněž předvídat cíl této cesty. Na samotném začátku cesty dochází k prvním známkám degradace člověka a jeho hodnoty. Tato dehumanizace se následně prohlubuje v prvních dnech pobytu v táboře.

6 Ibidem, s. 89-90.

7 Uniwersalny stownik jezyka polskiego. Stanisław Dubisz (red.). Warszawa: PWN, 2003, tom 3, s. 885.

8 PILECKI, Witold: Raport rtm. Witolda Pileckiego z 1945 roku. In: CYRA, Adam: Ochotnik do Auschwitz: Witold Pilecki (1901-1948). Oświęcim:Chrześcijańskie Stowarzyszenie Rodzin Oświęcimskich, 2000, s. 266.

9 JAWORSKI, Czesław Wincenty: Wspomnienia z Oświęcimia, Warszawa: Pax, 1962, s. 32. 
Rampa byla místem, kde měli nově příchozí vězni možnost poprvé se seznámit s táborovým prostředím a s jeho zákonitostmi. Okamžitě po vystoupení z vlaku, nebo dokonce ještě předtím, doléhal $\mathrm{k}$ jejich uším křik a na jejich těla dopadaly první rány:

Drzwi wagonu otworzyły się z trzaskiem, a z zewnątrz gruby podoficer wykrzykiwał: Alle raus! Loos, bewegt euch! Konwojenci, dotąd w miarę spokojni, skoczyli na nas, jakby dostali ostroge w bok. Waląc kolbami karabinów po plecach, wypchnęli nas z wagonów i wśrod niesamowitego wrzasku popędzali nas przez otwartą bramę $[\ldots] .{ }^{10}$

Krzyki, wrzaski, przeklęństwa, groźby, szalały i ogłuszały. Aż nadto wymowne miny i gesty nie pozostawiały najmniejszych wątpliwości, co będzie za chwilę.

Jak kto stał, chwytał co miał najbliższego pod ręką, i na pół ubrany, pozostawiając części garderoby oraz posiadanych rzeczy $[\ldots]$ wyskakiwał na peron. ${ }^{11}$

Ve výše citovaných ukázkách si opět můžeme povšimnout, jak se způsob přijímání nových transportů odráží v jazykové rovině. O atmosféře na rampě vypovídají použitá slovesa: wypchnać, popedzać a wyskakiwać. Místo poklidného vystupování z vlaku jsou vězni nuceni $\mathrm{v}$ nepřiměřeném tempu z něj vyskakovat a $\mathrm{v}$ tomto nastoleném rytmu, který je v táboře všudypřítomný a tedy pro něj charakteristický, pokračovat.

Vnímání rampy a dalších etap vstupu do tábora bylo silně ovlivněno předchozími zkušenostmi. Jinak reagoval na př́ijezd do tábora člověk mající za sebou zkušenosti z vězeňského prostředí nebo z ghetta a zcela odlišně přijímal tuto skutečnost ten, který byl dopaden při pouliční razii.

\section{b) brána}

Brána, jak již bylo v předchozí kapitole uvedeno, splňovala několik funkcí. Věnujme pozornost jedné z nich - funkci hranice mezi vnějším světem, který transport opouštěl, a izolovaným světem tábora, nebo jinými slovy mezi světem známým, vlastním a světem cizím. Současně tvoří hranici na časové ose - čas přítomný a minulý. ${ }^{12}$ Brána je místem vstupu a tím také přechodu. Projít branou znamená také změnit způsob vnímání prostoru, času, života, anebo viděno opačně - změna tohoto zpơsobu umožňuje vstoupit a projít. ${ }^{13}$

V koncentračním táboře Auschwitz-Birkenau bylo několik bran, z nichž jsou nejznámější dvě. Vstupní železná brána do kmenového osvětimského tábora s nápisem „Arbeit macht frei“ a také zděná brána se strážní věží v Birkenau, tzv. brána smrti. Brána, v jejímž chřtánu mizely transporty, je ve vzpomínkách vězňů zmiňovaná velmi sporadicky. Důvodem je zřejmě fakt, že touto branou transporty projížděly a vystupovaly až na rampě

10 ALBIN, Kazimierz: List gończy. Warszawa: Książka i Wiedza, 1996, s. 34.

11 REK, Tadeusz: Echa oświęcimskie. Warszawa: Wydawnictwo Ludowe, 1949, s. 55.

12 Viz také HODROVÁ, Daniela: Citlivé město: eseje z mytopoetiky. Praha: Akropolis, 2006, s. 279-280. Autorka se věnuje symbolice dveří, kterou je možné v tomto kontextu vztáhnout také na symboliku brány. Brána, stejně jako dveře, tvoří práh, hranici oddělující od sebe dva prostory. 
uvnitř táborového komplexu. Jejich pozornost je proto především soustředěna na toto místo. Můžeme však zmínit vzpomínky Bogdana Bartnikowského, který jel ve vagónu společně se železničářem dobře znajícím tratě v okolí Osvětimi:

- Brama Śmierci... - mówi kolejarz. - Poznaję... widziałem ją kiedyś z daleka. Wjeżdżamy pod Bramę Śmierci, do obozu, znaczy. To koniec... koniec z nami... pełno Niemców przy torze... to po nas...

- Może tylko przejeżdżamy, może się nie zatrzymamy i pojedziemy dalej...

- Nie, to ślepy tor, stąd nie ma wyjadzu... ${ }^{14}$

Mnohem více prostoru zaujímá v analyzovaných vzpomínkách vstupní brána kmenového tábora Auschwitz I. Zdá se, že také proto, že touto branou procházeli vězni pěšky, tudíž zřetelněji pocitovali její význam. Ztělesňovala skutečný předěl mezi vnějším a vnitřrním světem. Pozornost přitahoval také cynický nápis:

[...] zatrzymaliśmy się przy olbrzymiej żelaznej bramie, na której widniał duży, zachęcający napis: „Arbeit macht frei“. ${ }^{15}$

Jeho cyničnost však nebyla všem vězňům patrná hned při prvním překročení, a to z důvodu dezorientace po př́jezdu a také malé informovanosti o táboře.

Nie zdawaliśmy sobie sprawy, gdzie jesteśmy. Byliśmy pewni, że przyjechaliśmy do pracy. Tamtego dnia napis nad wejściem do obozu jeszcze dawał... nadzieję. ${ }^{16}$

Po pěším pochodu do tábora, během něhož se Grzegorz Timofiejew vnitřně vyrovnává s nastalými změnami, pozoruje ponuré okolí tábora, mísí se v něm strach se zvědavostí. V takovém rozpoložení nevnímal průchod branou jako zlomový okamžik.

Brama nie budziła przerażenia. Ot, taka sobie niepozorna, jakby małomiasteczkowa...Nad wejściem półkolem z drutów napis: Arbeit macht frei. Przeczytałem tę sentencję raczej uspokojony. To dobrze, że frei...17

Brána měla symbolický význam. Z pohledu eschatologické tradice je metaforizovaná jako brána do pekel:

W tej chwili przekroczyłyśmy bramę obozu. Odwróciłam się. Uświadomiłam sobie rzeczowo: „Jestem w obozie. Tu jest Oświęcim - Vernichtungslager - stąd nie ma powrotu."

14 BARTNIKOWSKI, Bogdan: Dzieciństwo w pasiakach. Warszawa: Nasza księgarnia, 1989, s. 9.

15 ALBIN, Kazimierz: List gończy. Warszawa: Książka i Wiedza, 1996, s. 41.

16 ZIÓŁKOWSKI, Michał: Bytem numerem 1055. In: PIECHOWSKI, Kazimierz: Byłem numerem...historie z Auschwitz. Warszawa: Wydawnictwo Sióstr Loretanek, 2010, s. 193.

17 TIMOFIEJEW, Grzegorz: Cztowiek jest nagi. Łódź: Wydawnictwo Łódzkie, 1960, s. 10. 
- Wstąpiłyśmy w piekło - powiedziała Zosia [...] i dodała: Czy będą nas smażyć, jak sądzisz? ${ }^{18}$

Nápis na bráně u mnohých vězňů vyvolával asociace s Dantovou Božskou komedii ${ }^{19}$, tak ho také interpretovali:

[...] zatrzaskiwano bramę obozową, na której drwiący napis : „Abeit macht frei” - „praca uwalnia”, posiadał dantejski sens: „dla wchodzących tutaj nie ma żadnej nadziei”. ${ }^{20}$

Z pekla není návratu, proto se v dílech objevují fatalistické předpovědi:

Za ostatnim zamknięto bramę. Koniec. Nikt już teraz nie ma wątpliwości, że tu pozostaniemy. ${ }^{21}$

Podobné předpovědi vyvolával u přijíždějících vězňů již samotný název cílové stanice jejich cesty:

- Auschwitz. Oświęcim. Obóz koncentracyjny. To już koniec koledzy. [...]

Starszy pan powtarzał z determinacją i smutkiem: - Obóz koncentracyjny.

To koniec! ${ }^{22}$

Druhá tradice, kterou můžeme jmenovat, je tradice východní filozofie. Odkaz na moudrost východních myslitelů uvádí Witold Pilecki. Čínský aforismus, který by měl přinést naději, však v autorovi vzbuzuje spíše hořkost:

Zbliżaliśmy się do bramy, umieszczonej w ogrodzeniu z drutów, na której widniał napis: „Arbeit macht frei“. [...] Wysoki, wtedy jeszcze pojedynczy płot z drutu kolczastego i brama pełna esesmanów nasunęly mi mimowolnie, czytany kiedyś aforyzm chiński: „Wchodząc, pomyśl o odwrocie, a wychodzić będziesz cało...“ Uśmiech ironiczny zrodził się gdzieś we mnie i przygasł... na co to tutaj się przyda... ${ }^{23}$

Místo popisu vnitřních pocitů, emocí, které vězni při své první cestě do tábora pocitovali, mnozí autoři zmiňují drobné detaily, jichž si povšimli. Gogołowska se při procházení branou nesoustřed'uje na své vnitřní rozpoložení, ale uvádí to, co jí utkvělo v paměti. Její pozornost upoutaly květiny jako výrazný kontrast k táborovému prostředí. Je pravděpodobné, že barevnost květin pro ni byla zajímavá také vzhledem k předchozí několikaměsíční izolaci ve lvovském vězení.

18 ŻYWULSKA, Krystyna: Przeżytam Oświęcim. Warszawa: doM wYdawniczy tCHu, 2011, s. 14.

19 Viz nápis na pekelné bráně: „Kdo vchází mnou, necht̉ naděje se zhostí“ (DANTE Alighieri: Božská komedie. Brno: Trubin, 2007, část Peklo, III, 9).

20 REK, Tadeusz: Echa oświęcimskie. Warszawa: Wydawnictwo Ludowe, 1949, s. 87.

21 SZACHEWICZ, Mieczysław: Noce bez świtu. Warszawa 1978, s. 24.

22 KOWALCZYK, August: Refren kolczastego drutu. Pszczyna: Urząd miejski, rok vydání neuveden, s. 71-72.

23 PILECKI, Witold: Raport rtm. Witolda Pileckiego z 1945 roku. In: CYRA, Adam: Ochotnik do Auschwitz: Witold Pilecki (1901-1948). Oświęcim:Chrześcijańskie Stowarzyszenie Rodzin Oświęcimskich, 2000, s. 267. 
Tuż przed bramą stoi dom otoczony trawnikiem, klomby, kwiaty...ile czasu to nie widziałam kwiatów... ${ }^{24}$

Podobně se vyjádřila také vězenkyně, která dokázala vnímat krásu stromů rostoucích v blízkosti brány:

Mijamy bramę z napisem „Arbeit macht frei”. Piękne wysokie drzewa, za nimi budynek lub budynki [...] Czy skręcimy w stronę pięknym drzew?25

Můžeme si klást otázku, proč v tak vypjaté situaci nově příchozí vězenkyně upoutaly tyto detaily. A možná právě vypjatost situace byla příčinou toho, že jejich pozornost byla upřena na zdánlivě bezvýznamné maličkosti, jež představovaly květiny či krásné stromy. Autorka si již dobře nevzpomíná, jestli míjela jednu nebo více budov, nicméně si vybavuje krásu stromů, které vytvářely kontrast k ponurému a neosobnímu prostředí tábora a mohly navozovat pocit domova, jenž byl tak vzdálený.

Odvést pozornost a poskytnout nadhled na bezvýchodnou situaci rovněž pomáhal vězňům černý humor. Šířilo se mezi nimi rýmované dvojverší inspirované nápisem na bráně:

Arbeit macht frei, durch krematorium drei. ${ }^{26}$

Brána tvořící hranici s vnějším světem poskytovala vězňům první možnost nahlédnout do izolovaného světa tábora. Odhalovala tak tajemný prostor, jenž naháněl hrůzu, ale také vzbuzoval velkou zvědavost. První kontakt s novým prostředím přinášel mnohdy značné rozčarování a nepochopení.

Za drutami, na wielkim placu, uderzył nas inny widok. W nieco fantastycznym, pełzającym po nas ze wszystkich stron świetle reflektorów, widoczni byli jacyś niby-ludzie. [...] W dziwnych ubraniach w pasy, jakie się widziało w filmach o Sing-Sing, z orderami na kolorowych wstrzążkach (jak mi się wtedy w migającym świetle wydawało). ${ }^{27}$

Místo aby brána vyvolávala šok a dezorientaci, představovala místo, kam se upírala zvědavost nových vězňu:

Był dzień Barburki, 1940 r., kiedy stanęli pod bramą z napisem „ARBEIT MACHT FREI”. Od-

24 GOGOŁOWSKA, Stanisława: W Brzezince nie umierato się samotnie. Warszawa: Książka i Wiedza, 1973, s. 10.

25 MÜLLER-MADEJ, Stella: Oczami dziecka: Wspomnienia z dziecinstwa w getcie $i$ obozach koncentracyjnych. Kraków: nakład własny autorki, 1991, s. 95.

26 KURASZKIEWICZ, Władysław: Jezyk polski w obozach koncentracyjnych. Lublin: vydavatel neuveden, 1947, s. 12.

27 PILECKI, Witold: Raport rtm. Witolda Pileckiego z 1945 roku. In: CYRA, Adam: Ochotnik do Auschwitz: Witold Pilecki (1901-1948). Oświęcim: Chrześcijańskie Stowarzyszenie Rodzin Oświęcimskich, 2000, s. 267. 
dychali pełną piersią, mroźnym grudniowym powietrzem, bardziej ciekawi niż przerażeni tym, co ich za tą bramą czeka. Nie wiedzieli wówczas, co to jest Oświęcim. Żyli i czekali. ${ }^{28}$

První překročení brány je začátkem liminální fáze rituálu. Poté, co ji vězeň překročí, získává nový status a vstupuje do zcela odlišného časoprostoru. Než se plně zapojí do táborového života, prochází karanténou, jež je možné vnímat jako dílčí sekvenci rituálu odluky, čili odloučení od dosavadního světa a začátek procesu přeměny.

\section{c) sauna}

Začátkem procesu přeměny, kterou bychom mohli pojmenovat také jako dehumanizace, jejímž cílem nebyla jen proměna zevnějšku, ale také potlačení individuality. Tento proces se skládal z několika kroků, které se v jistých detailech lišily, tábor od tábora, a v průběhu let se také upravoval. V počáteční fázi existence osvětimského tábora celý proces otevíral uvítací proslov, jehož snahou bylo vězně především zastrašit:

Niech nikt z was nie sądzi, że kiedykolwiek wyjdzie stąd żywy... porcja jest tak obliczona, że żyć tu będziecie 6 tygodni; kto będzie żył dłużej...znaczy, że kradnie, kto kradnie, znajdzie się w SK - gdzie żyje się krótko! ${ }^{29}$

V projevu, kterým vítal zástupce velitele tábora Fritz Seidler nově příchozí vězně, byla zcela zřetelně deklarována pravidla panující v táboře, byl jednoznačně popsán osud, jenž byl pro každého vězně připraven. Z projevu byl jasně patrný vztah esesmanů k vězňům a k hodnotě jejich lidského života. Seidlova slova byla výsměchem a zároveň měla vězně hned v první chvíli zastrašit, potlačit jejich snahu o vzpouru a zbavit je jakékoliv naděje, že bojovat za svi̊j život má stále smysl.

Zvláště ženy, které přijížděly do Birkenau, vzpomínají na to, že po př́ijezdu byly zahnány do nějaké budovy, v níž strávily několik hodin, často však čekaly celou noc. Bez jídla, vody a bez jakýchkoliv informací, co bude následovat.

Wpuścili nas do jakiegoś baraku. Położyłyśmy się na podłoze, my, Zosie, Stefy, Hanki, złączone aż do śmierci grozą, bólem, strachem i przyjaźnią.

Jedna myśl tłukła się we wszystkich głowach, nie pozwalała usnąć ani leżeć spokojnie:

Jakie będzie jutro? ${ }^{30}$

I toto čekání je součástí přechodového rituálu. Vězeň již překročil „práh“ tábora, tj. vystoupil na rampě z vlaku a nachází se na cestě k přijetí nové identity. Stále jej ještě můžeme považovat za „cizince“. Společnost pobývající v táboře již delší dobu se k nově příchozím v tento okamžik chovala podobně, jako se chovají mnohé domorodé národy

28 MAKUSZEWSKI, Zbigniew: Od berbecia do rupiecia... Tom 1. Sopot: Zbigniew Makuszewski, 1999, s. 260.

29 PILECKI, Witold: Raport rtm. Witolda Pileckiego z 1945 roku. In: CYRA, Adam: Ochotnik do Auschwitz: Witold Pilecki (1901-1948). Oświęcim: Chrześcijańskie Stowarzyszenie Rodzin Oświęcimskich, 2000, s. 269 .

30 ŻYWULSKA, Krystyna: Przeizytam Oświęcim. Warszawa: doM wYdawniczy tCHu, 2011, s. 17. 
k cizím návštěvníkům. Cizinci přicházející na území domorodých národů nemají bezprostřední právo vstoupit na určitá místa, nacházejí se tak ve stavu izolace. Cizinec mohl být také vnímán jako posvátná bytost mající magicko-náboženskou moc, at̉ už blahodárnou nebo negativní, proto také rituály, jimiž cizinci procházeli, měly jejich moc mírnit, neutralizovat nebo přeformovat na blahodárnou. ${ }^{31}$ Nelze se domnívat, že by personál tábora a jejich prodloužená ruka v podobě vězňů vykonávajících určité funkce považovali nově příchozí za posvátné bytosti. Nicméně jejich izolace, v níž museli čekat - napjatě nebo se zvědavostí a bez ohledu na své potřeby (hlad, spánek) - měla vést k tomu, aby se neutralizovala nebo výrazně utlumila jejich fyzická a duševní síla, která by mohla být zdrojem snah klást odpor. Ačkoliv s vězni nikdo nekomunikoval a z budovy, v níž pobývali, nebyl dobrý výhled, mohli už jen svou přítomností v blízkosti tábora nasávat atmosféru celého systému. Toto dokládá také úryvek ze vzpomínek Krystyny Żywulské: když se ráno otevřely dveře budovy, začaly dovnitř nahlížet vězenkyně a vyptávat se na své známé, o nichž si myslely, že by mohly být také dopadeny a přivezeny sem. Pohled na ně byl šokující, nicméně po jedné noci strávené v táboře, autorka vzpomínek sama přichází na to, že v těchto podmínkách se tomuto stavu není možné vyhnout a že i ji čeká naprosto stejný osud:

Tak będziemy wyglądać. Wiedziałyśmy to już bez słów. ${ }^{32}$

Nebylo třeba se na nic ptát, ani očekávat odpověd'. Stačila jedna noc, aby každá nová vězenkyně pochopila pravidla života v táboře.

Po této zkušenosti přistupovaly vězeňkyně $\mathrm{k}$ registraci. Veškeré úkony registrace v sobě nesou typické znaky odlučovacích rituálů. Dle Van Gennepa spadají do této kategorie rituálů všechny, při nichž se „něco odřezává“. Zejména se jedná o střrihání vlasů, holení nebo o rituál prvního oblékání. ${ }^{33}$ Takovéto procedury zahrnovala také registrace v táboře. Ženy oproti mužům intenzivněji prožívaly jednotlivé úkony aktu proměny, proto mu ve svých dílech věnují mnohem více prostoru. Nejprve musely odevzdat veškerý svůj oděv a drobné předměty - památky na své blízké a na svůj domov. V další fázi bylo nutné se vyrovnávat se svým studem a snášet pohledy dohlížejících dozorců. ${ }^{34}$ První procedurou zpravidla bylo stř́íhání vlasů a veškerého ochlupení. Důvody k této proceduře byly nejen hygienického charakteru, ale také psychologického. Vězeň zbavený vlasů cítil značné ponížení, současně si uvědomoval, že přichází o část své individuality, důstojnosti, na což ale v konečném důsledku reagoval svou rezignací. Zvláště ženy vnímaly akt „postřižin“ velmi emocionálně:

31 VAN GENNEP, Arnold: Přrechodové rituály. Praha: Lidové noviny, 1996, s. 32-33.

32 ŻYWULSKA, Krystyna: Przeżytam Oświęcim. Warszawa: doM wYdawniczy tCHu, 2011, s. 18.

33 VAN GENNEP, Arnold: Přechodové rituály. Praha: Lidové noviny, 1996, s. 57.

34 Nutnost svléknout se do naha a odevzdat svůj veškerý oděv symbolizuje ukončení a rozloučení se s dosavadním životem. Nahota byla přijímána vězni jako velmi silný akt ponížení a neúcty. Postoj k nahotě je nutné vnímat skrze pravidla tehdejší morálky, na což poukazuje také Helena Dunicz Niwińska. (Viz DUNICZ NIWIŃSKA, Helena: Drogi mojego życia: Wspomnienia skrzypaczki z Birkenau. Oświęcim: Państwowe Muzeum Auschwitz-Birkenau, 2013, s. 49). Vězni si na nahotu museli přivyknout, protože byla naprosto samozřejmou součástí táborového života. Při hromadné koupeli nebo při společném používání latrín byli vězni okolnostmi donuceni se svlékat do naha. 
Na podłodze rośnie sterta włosów. Już moja kolej. Usiadłam. Jakże strasznie boleśnie targają tą maszynką, to rwanie, nie golenie. Nie potrafię opanować łez. [...]

Stanęłam oboz Ilzy. Nie chcę, nie mogę patrzeć, kiedy zaczną padać blond włosy mojej mamusi. Ilza wzięła mnie za rękę.

- Nie płacz, kochanie, nie płacz, byle została głowa, to włosy odrosną. A czy wiesz, jak ci ładnie? Śliczną masz głowę, równiutką, okrągłą, z tymi wielkimi czarnymi oczami wyglądasz jak lalka. Tylko nie placz. ${ }^{35}$

Próbowałyśmy żartować, ale wyglądałyśmy jak maszkary. I wszystkie byłyśmy do siebie podobne. Nigdy nie sądziłam, że włosy nadają tyle indywidualności. ${ }^{36}$

Následovalo tetování čísla, které ve vězních ještě více umocnilo pocit ponížení a beznaděje. Ze všech procedur rituálu odluky mu věnují nejvíce pozornosti.

Kłuła mnie właściwie nie w rękę, lecz w serce - tak to czułam.

Od tej chwili przestałam być człowiekiem. Przestałam odczuwać, pamiętać. Umarła wolność, mama, przyjaciele, domy, drzewa. Nie miałam już nazwiska, adresu. Byłam Häftlingiem nr 55908. I w tej minucie, za każdym ukłuciem odpadał jakiś okres życia, którym żyłam, a zaczynało się otępienie, w którym miałam żyć...jako numer. ${ }^{37}$

Otrzymany numer miał od tej chwili zastępować imię chrzestne, nazwisko panieńskie, mężowskie, przydomek, pseudonim, rodowody, pieszczotliwe nazwania, metrykę, wszelakie dokumenty, dowody osobiste..$^{38}$

Ztráta jména znamená ztrátu identity a svých vlastních kořenů. Tento akt velmi citelně odděluje každého vězně od jeho dosavadního života. Ztráta vlastního jména nezpůsobuje bolest na těle, ale především na duši. Jméno je nahrazeno číslem, tudíž dochází k proměně od „někdo“ k „něco“. Vězeň přestává být z pohledu německých dozorců člověkem, který měl vlastní život, rodinu, kariéru, minulost a stává se pouze věcí, číselnou položkou v seznamu. Bartłomiej Krupa hovoří o transgresi a transformaci vězně. Přidělení čísla je vnímáno jako apogeum celého přechodového rituálu. ${ }^{39} \mathrm{Na}$ jedné straně můžeme tento akt vnímat jako vyvrcholení rituálu odluky, protože dochází k citelné ztrátě identity, zároveň však je v této proceduře možné pozorovat prvky přijímacího rituálu. Vězňovo pravé jméno je nahrazeno číslem, které je pro něj „vstupenkou“ do nové táborové společnosti. V tuto chvíli získává nový společenský status. ${ }^{40}$

35 MÜLLER-MADEJ, Stella: Oczami dziecka: Wspomnienia z dzieciństwa w getcie $i$ obozach koncentracyjnych. Kraków: nakład własny autorki, 1991, s. 96.

36 ŻYWULSKA, Krystyna: Przeizytam Oświęcim. Warszawa: doM wYdawniczy tCHu, 2011, s. 20.

37 Ibidem, s. 19.

38 KOSSAK, Zofia: $Z$ otchtani. Warszawa: Książka i Wiedza, 2011, s. 23.

39 KRUPA, Bartłomiej: Wspomnienia obozowe jako specyficzna odmiana pisarstwa historycznego. Kraków: Universitas, 2006, s. 105.

40 Viz VAN GENNEP, Arnold: Přechodové rituály. Praha: Lidové noviny, 1996, s. 65. Van Gennep hovoří 
S nově získanými čísly se spojovala symbolika čísel, na jejímž základě se předvídal osud čekající na jeho nositele v táboře.

Ja miałem numer 4859. Dwie trzynastki (ze środkowych i skrajnych cyfr), utwierdzały kolegów w przekonaniu, że zginę; mnie - cieszyly. ${ }^{41}$

Rituál přijetí jména (v tomto případě však čísla) je často spojován se křtem nebo s rituální lázní. Voda měla za úkol smýt ze člověka vše nečisté a oddělit jej od dosavadního života. ${ }^{42}$ Krátká koupel během registrace vězňů v táboře může být vnímána jako metafora křtu. ${ }^{43}$

Transformace vězně do jeho nového sociálního statusu je završena přidělením nového oblečení. Je známo, že oděv vypovídá o postavení jeho nositele, totéž lze říci o vězních. Jejich pruhovaná uniforma, na níž si posléze přišili svá čísla a trojúhelník určité barvy, jenž hovořil jasně o prríčinách jejich deportace, představovala vnější znak jejich postavení. Status vězně v táboře určovala také páska nošená na levé paži.

\section{d) karanténa}

Výše uvedené procedury představují transformaci člověka, nově příchozího vězně zuganga, cizince šokovaného táborovou realitou do jeho nového statusu - häftlinga. Než došlo po tomto rituálu odloučení k začlenění do nové společnosti, pobývali nově příchozí vězni v karanténě. Karanténa, jak název napovídá, byla oficiálně zřízena jako izolační prostor z hygienických důvodů ve zvláštních vyhrazených blocích. Vězni zatím neměli povinnost pracovat, za to trávili dny vyčerpávajícím sportem, drilováním povelů nebo německých písní. Tak tomu bylo v př́ípadě mužů vězněných v Auschwitz. Ženy vězněné Birkenau trávily většinu času na tzv. „louce“.

Tento přechodný stav popsal Adol Gawalewicz:

Po paru godzinach zdaję sobie jasno sprawę [...] - że przestałem już być człowiekiem, a nie stałem się jeszcze więźniem obozu, jestem najnędzniejszym stworem, który nazywa się Zugang (nowo przybyły). ${ }^{44}$

o rituálu pojmenovávání dětí, př̌i němž je dítě přijímáno do společnosti. Tento akt lze metaforicky vztáhnout také na přidělování čísel v koncentračním táboře.

41 PILECKI, Witold: Raport rtm. Witolda Pileckiego z 1945 roku. In: CYRA, Adam: Ochotnik do Auschwitz: Witold Pilecki (1901-1948). Oświęcim: Chrześcijańskie Stowarzyszenie Rodzin Oświęcimskich, 2000, s. 269.

42 Viz VAN GENNEP, Arnold: Přechodové rituály. Praha: Lidové noviny, 1996, s. 65.

43 Nejen koupel závěrem registrace, ale všechny procedury registrace včetně pobytu v karanténě byly vnímány jako určitý „,křest“. Zmiňuje se o tom Zbigniew Makuszewski: „Obrzędem integralnym związanym z przybyciem do obozu i włączeniem do lagrowego społeczeństwa, był swoisty »chrzest «". Viz MAKUSZEWSKI, Zbigniew. Od berbecia do rupiecia... Tom 1. Sopot: Zbigniew Makuszewski, 1999, s. 281

44 GAWALEWICZ, Adolf: Refleksje z poczekalni do gazu: Ze wspomnień muzutmana. Oświęcim: Państwowe Muzeum Auschwitz-Birkenau, 2009, s. 49. 
Karanténa byla pomezím, mezičlánkem spojujícím sakrální a profánní čas tábora. Toto období sami vězni velmi často označují výrazem „zaprawa“ - čili příprava. Karanténa byla předstupněm skutečného táborového života:

Dni płynęły wolno, odmierzane przedpołudniową i popołudniową porcją ćwiczeń na placu w upale dochodzącym do trzydziestu stopni, urozmaiconych wymyślnymi szykanami znudzonych oprawców. Wszystko to miało być zaprawą do życia obozowego, okresem kwarantanny, morderczą szkołą rekrucką pruskiego drylu. ${ }^{45}$

Nalezneme však i jiná pojmenování. Pobyt v karanténě byl vnímán také jako „očistec“, jenž může být také chápán jako určitý druh „přípravy“. V tomto případě však tradiční eschatologické pojetí očistce jako předstupně ráje, během něhož dochází k očištění duše od drobných hříchů, nelze použít. Karanténa měla člověka „očistit“ od všech jeho lidských vlastností, oddělit jej od dosavadního života, uvést v zapomnění a otupit jeho smysly. Byla to zkouška fyzické i psychické zdatnosti, kdo jí prošel, na toho nečekal žádný „ráj“, ale vstup do „pekla“. Setkáváme se tedy s naprosto odlišnou posloupností - očistec je v př́ípadě koncentračních táborů předstupněm pekla.

Kto jednak przetrwa i ujdzie z życiem z tego czyśćca, ten jest już w pewnym sensie uodporniony i zaprawiony do dalszej kategorii obozowej. ${ }^{46}$

„Ráj“ nebo také „nebe“ představovaly v táboře ironické označení pro krematorium. ${ }^{47}$ Můžeme tedy sestavit následující schéma uplatňované v táboře: očistec - peklo - ráj. Ráj, který je obecně chápán jako místo dokonalé harmonie, naplněné štěstím a pokojem, v němž nevládne utrpení, nebo jako stav vykoupené duše zemřelého člověka, jež se raduje z pobytu v boží přítomnosti. V táborovém prostředí je tomuto pojetí přrikládán ironický až sarkastický význam, čímž je dehonestován.

Období karantény, jak již bylo výše uvedeno, představovalo další fázi dehumanizace člověka, snahu učinit z něj naprosto poslušnou jednotku, která nebude schopna klást sebemenší odpor. Cvičení i jiné formy teroru ve spojení s nedostatečnou stravou vedly k postupné ztrátě fyzické síly a rovněž k psychické apatii:

Najpierw trzeba było zdusić duszę w człowieku, zabić w nim jego ego, zrobić z niego szmatę, zmienić go w stworzenie, które tylko chce jeść i nic więcej. Kiedy już to się udało, można było skierować takich stłamszonych, przybitych i poniżonych do roboty. ${ }^{48}$

45 ALBIN, Kazimierz: List gończy. Warszawa: Książka i Wiedza, 1996, s. 39.

46 GOGOŁOWSKA, Stanisława: W Brzezince nie umierato się samotnie. Warszawa: Książa i Wiedza, 1973, s. 51.

47 Kolasiński vzpomíná, když při pochodu do tábora míjeli vysoké komíny krematoria, jejich konvoj utrousil ironickou poznámku: „Das ist euer Paradies!“ („To jest wasz Raj!“) Viz KOLASIŃSKI, Bogdan:Jakim cudem jeszcze żyje...? Oświęcim: Państwowe Muzem Auschwitz-Birkenau, 2006, s. 73.

48 PIECHOWSKI, Kazimierz: Bytem numerem...historie z Auschwitz. Warszawa: Wydawnictwo Sióstr Loretanek, 2010, s. 26. 
Ženy v Birkenau si jako obranu proti této dehumanizaci a také smysluplnou formu, jak si zkrátit dlouhé chvíle sezení na tzv. „louce“, vymyslely klub, jehož náplní byly referáty různého druhu. Jejich cílem byla nejen psychická podpora vězenkyň, ale i touha zapomenout na hlad a nenechat se pohltit táborovou realitou.

Jaki na dziś referat? Wczoraj Łucja Charewiczowa opowiadała pięknie o ukochanym przez siebie Lwowie, o jego wielkiej przeszłości.[...] Przedwczoraj, Joanna Kunicka, profesor psychologii, przeprowadziła długą i uczoną dysertację na temat: „Czy bez wiary można być szczę́liwym?” Dowodziła, że tak. Wnet wyłonił się koreferat o założeniu przeciwnym, potem nastąiła ogólna zapalona dyskusja. [...] Zagadały się tak, że zapomniały o głodzie. ${ }^{49}$

Přechod z karantény do tábora probíhal prostřednictvím velmi jednoduchého rituálu. K ukončení období karantény došlo tak, že vězeň opustil zvláštní vyhrazený blok pro nově příchozí a přestěhoval se na jiný. Kromě toho začíná každý vězeň pracovat. Popisy tohoto přechodu jsou velmi lakonické, což svědčí o tom, že již nepředstavoval tak výraznou změnu, i když ve skutečnosti mohl být dramatický, nebot každý vězeň se snažil dostat se k té co možná nejlepší práci a zajistit si co možná nejsnesitelnější životní podmínky.

Następnego dnia przeniesiono nas z kwarantanny do bloku nr $2 .{ }^{50}$

Dosyć tresury. Musimy znaleźć pracę w komandzie albo otrzymamy przydział od Arbeitsdiensta. ${ }^{51}$

Detailněji se o ukončení období karantény zmiňuje Kazimierz Albin, který uvádí, že před vstupem do tábora procházel podobnými procedurami jako při první registraci:

Wreszcie przyszła kolej na nas - okres kwarantanny minął. Codziennie odprowadzano nas grupami do obozu. Pewnego dnia sformowani w piątki, sprzężystym krokiem pomaszerowaliśmy do łaźni, potem przebrani w pasiaste mundury udaliśmy się szeroką aleją w stronę kompleksu budynków ogrodzonych drutem kolczastym [...] Przeliczeni przez esesmana, wkroczyliśmy do obozu. ${ }^{52}$

\section{Mgr. Markéta Páralová Tardy}

Ústav slavistiky, Filozofická fakulta, Masarykova univerzita

A. Nováka 1, 60200 Brno, Česká republika

mparalova@centrum.cz

49 KOSSAK, Zofia: Z otchtani. Warszawa: Książka i Wiedza, 2011, s. 47.

50 KIELAR, Wiesław: Anus mundi: Wspomnienia oświęcimskie. Kraków: Wydawnictwo Literackie, 1976, s. 35.

51 ZIÓŁKOWSKI, Michał: Bytem numerem 1055. In: PIECHOWSKI, Kazimierz: Byłem numerem... historie z Auschwitz. Warszawa: Wydawnictwo Sióstr Loretanek, 2010, s. 208.

52 ALBIN, Kazimierz: List gończy. Warszawa: Książka i Wiedza, 1996, s. 41. 